\title{
How to Do Well the Ideological and Political Education Work of College Students in the New Situation Liu Jiangping
}

\section{Public Security Fire Force College ,Kunming 650208,China}

Keywords: New Situation of Ideological and Political Education

Abstract. Political work relationship forces building the overall and direction. The political work of the university is directly related to the overall direction of the school construction and development, which is related to the successful completion of the personnel training goal. In order to ensure that the army building a firm and correct political direction, to ensure that the military academies to train qualified personnel qualified, in the face of the new situation and new tasks, we must firmly grasp the ideological and political education

Chairman of the school pointed out that ideological and political construction is the fundamental construction of our army, must always be placed in the construction of the first task, to ensure that the army is absolutely loyal, absolutely pure, absolutely reliable. Under the new situation, the students of the contingent academy have profound changes in the aspects of ideas, values, and attitudes of life. They have made new demands and new puzzles, and put forward new demands and challenges for the work of military management education. In the face of the new situation and new tasks, we must firmly grasp the ideological and political education work, to ensure that the army building a firm and correct political direction, to ensure that the military institutions to cultivate the political qualifications of qualified personnel. This article discusses the ideological and political education work of college students in connection with the actual development of military academy.

\section{Always put ideological and political education in the construction of the first place to ensure that the political orientation of personnel training}

Political work relationship between the overall situation and direction of the army, is our army's biggest feature, the biggest advantage, but also our army to maintain the nature of the people's army, purpose, character of the important guarantee. The political work of the university is directly related to the overall direction of the school construction and development, which is related to the successful completion of the personnel training goal.

1.1We must follow the law to grasp the ideological work and perceive the powerful power of political work.

Ideological and political education is ideological work, do a good job of ideological work, is to solve the officers and men "what flag", "what way", "who go", "service who" the inevitable request for the realization of the party The goal of strong military forces under the new situation is of great significance. Grasp the ideological work to seize the absolute loyalty to ensure that the army is absolutely pure, absolutely reliable source. In the ideological and educational work of the military academy, we should let the officers and men of the whole school make clear that "there are political and cultural infiltration among the words, there are temptations in the network, there are traps in the exchanges", we must follow the inherent law of ideological construction , To actively seize the attitude to master the initiative to win this no smoke of the war. First of all, we must put the firm belief as the core content, to solve the "letter what" problem; Secondly, we must resist the wrong trend as a 
key link to solve the "anti-what" problem; Finally, we must adhere to political discipline as a basic requirement, Good "keep what" problem.

1.2To establish the ideological and political work "the first consciousness", from the President of the political work of high concern in the importance of cognitive political work.

It is the first of the president to discuss the important issues concerning national defense and army building from the ideological and political construction and mastery of the army. Since the 18th National Congress of the Communist Party of China (CPC) has repeatedly published important discussions on the role of "lifeline" in political work, the president has adopted the "housekeeping skills", "the biggest features", "the biggest advantage", "the biggest difference", "important guarantee "We have profoundly expounded the important position and important role of the" lifeline "of our military's political work, and pointed out that" the revolutionary political work has been carried out to ensure that our army is always the revolutionary army under the absolute leadership of the Party and defeats the powerful enemy and hard for our army The risk of providing an inexhaustible force, so that our army has always maintained the people's army of character and style, "stressed that" must be a profound understanding of strengthening the political work of the army's extreme importance, extreme necessity, extreme urgency. "

1.3Looking to the future, from the new historical mission tasks well aware of the great significance of political work.

The situation determines the task, the task leads the development. Clarifying the task requirements is the prerequisite and basis for strengthening and improving political work. In the face of the development and change of the times, the political work of the military academies can only play the advantages of personnel training in order to enhance the vitality and enhance the combat effectiveness standards. In the work of ideological and political education, colleges and universities should highlight the status of the fighting fortress of political work, establish the "lifeline" consciousness, to grasp the political school is tight and tight, real and real, to tit for tat, confidently, in a clear-cut struggle The Especially in the current situation of tension at home and abroad, the ideological struggle in the field of sharp and complex, hostile forces to intensify the implementation of Westernization, differentiation, attempt to shake the party's absolute leadership of the military, etc., political work can only strengthen can not be weakened, Stagnation, can only be actively unable to be passive response, we must resolutely correct all despise, relax, damage the political work of thinking and behavior, we must always adhere to the political school policy, always adhere to the political work "lifeline" status unwavering, School firm firmly in the right direction escort.

\section{To do more measures, focus on ideological and political education of the overall planning}

2.1Strengthen and guide, fulfill the duties of the party committee organs.

To promote the political work of the military academy "lifeline" to maintain the "vitality", the most important thing is to keep pace with the times continue to promote political work innovation and development, the party committee organs to take the lead, duty, do " The Political work is the party's ideological work and organizational work in the army. In the work of the institutions, one is to plan well. At the beginning of each year, according to the spirit of the higher party committees and unified arrangements, the inclusion of large-scale education into the annual work plan and political work of 
the party committee, the theme of education, basic education and situation policy education overall design, and grass-roots trainees squadron independent education Content to guide the views of the use of quarterly meetings to determine the theme of education and learning priorities, adjust the diversion of educational content, coordination and resolution of outstanding contradictions; In accordance with the idea of "merging the same type, the total amount is not owe", according to the intrinsic link of the educational content, the related combination, the repetition of the deletion, the non-individual organization that can integrate into the subject education, Reduce redundancy, improve the quality of education. Three to regain the system. Adhere to the regular implementation of the party committee teaching system, timely study and solve the problems encountered in the overall education; conscientiously implement the investigation and analysis system, accurately grasp the ideological and ideological base, clearly the next step education focus and direction; strict implementation of education centralized management system, To avoid teaching a number of doors, and effectively maximize the quality of education to play out.

2.2Innovation, the use of flexible and efficient form of the method.

In the ideological and political work in the development of institutions, we must pay attention to ways and means of innovation. First, to extend the classroom to enliven the education. The education content bound to small education activities, a good culture into the study life and work. Second, it is necessary to meet the needle to engage in education. Actively carry out "random education", after class meals, training gaps, master thinking, solve practical problems. Third, we should focus on the situation to engage in education. Around the current strength of the military goals, the situation at home and abroad, the new problems facing the construction of troops, etc., launched the school officers and men to carry out hot events, read newspapers and other activities, through the thought of confrontation, point of view collision, clarify right and wrong, keep in mind the mission, firm belief.

2.3Integration of resources, play a good variety of resources, the actual performance.

Under the new conditions to conform to the trend of information technology, we must use new media, new technology to carry out political work, improve the quality of political education, and effectively into the political work of the era of elements. First of all, to make a good variety of learning materials. Party committees at all levels should regard the spirit of all levels of documents, counseling books and learning reference as an important teaching material, combined with theoretical study, political education, the original book to learn the spirit of the document repeatedly. Second, the occupation and construction of online political work positions, the establishment of learning garden, to carry out online learning activities, timely release of learning dynamics, exchange experience, show the results of learning. Finally, we should use good media media, adhere to good news, read newspapers, listen to radio teaching activities, to maintain the correct guidance of public opinion; widely carried out "see red movies, tell the red story, sing the red song" and other mass activities, Blood screen, each of the feudal warfare, each of the classic works, each fighting slogan education infected students. At the same time, we must strengthen the thinking of the rule of law, improve the system of running the system according to law, adhere to the guidance and work in accordance with the law, to promote political work to the legalization of the track. Depth study and measures to strengthen the improvement of political work measures, the introduction of modern management 
concepts, strengthen the standardization of construction and process of fine management, improve the work guidance and mode of operation, improve scientific planning, scientific organization, scientific implementation of political work ability level.

\section{And constantly strengthen the ideological and political education team building, and strive to build a party loyalty, fighting strong, good style of ideological and political education cadres}

3.1Give Full Play to the Main Force Role of Political Instructors in Colleges and Universities.

Political instructors as the troops of the "party" and "student soul of the engineers", responsible for the heavy ideological and political work tasks, the party building tasks and the task of building a comprehensive army, work hard, things complicated, honorable, significant responsibility. In the training of political instructors, the first focus on "election" link, adhere to the standard, the amount of application, to solve the problem with the team. First, the good political instructor of the "election" off, each year with the cadre performance appraisal, the direction and potential of the cadres to conduct a comprehensive analysis, the use of "sub-pool water" approach, establish and improve the instructor "talent pool"; To strictly "entrance", the real maturity of those who are mature, comprehensive quality, style decent, familiar with the political business of the cadres matching to the instructor post. At the same time smooth "export", decisive on the energy to move, negative to meet the quantitative assessment of the rank of the instructor, transferred from the leadership positions, optimize the instructor team matching. The third is to play the role of "encourage", clear responsibilities, establish a guide, solve ideological problems, focus on guiding the political instructors to play the branch secretary "leader" role, continue to inculcate the student team "something to find branch" consciousness, highlight the status of instructors. Fourth, enrich the "education" approach, to strengthen the professional training of political instructors to enhance the overall quality. We should advance the work of the political instructor and the training of the cadre promotion training, the deputy secretary of the party branch, and so on, and through the invitation of some senior experts, to carry out systematic counseling training, pay attention to cultivate the team's taste, level and other comprehensive quality, Whole force.

3.2Vigorously improve the team cadres to grasp the ability of ideological and political education management.

To enhance the ability of cadres and ideological and political education management, party committees at all levels to do the following "four help work." One to help the cadres to establish the correct "post" consciousness. Instructors, instructors of the duties, tasks, division of labor, etc., "Political Work Ordinance" which clearly stipulates that the education team cadres must act according to regulations, strictly perform their duties, so that political workers do not vacant, good bit, not offside. Second, to help the team cadres to establish a correct "first" consciousness. "The first consciousness" is "service and guarantee". "Service" does not mean that the subsidiary to follow, but the overall situation, the majority of grassroots officers and men; "guarantee" does not mean protection, but their own positive, and to ensure their team and political position in the firmness and correctness. Three to help the team cadres to establish a correct "authority" consciousness. Political leaders should work together with the military officer to carry out the work, is mainly responsible for 
team management and ideological and political work, and truly do not do anything, do not hesitate to make a statement, do not seek power, Four to help the team cadres to establish a correct "example" consciousness. The power of example is infinite, it is by their own quality and behavior of an influence, it is not given by the organization, but their own. The old saying: "The body is not, and not the line, its body is not correct, though not from", "to teach from the people to teach," so that political workers to become the team members of the banner and example, in order to more forcefully The formation of troops, "the wind is clean gas, honest and honest, first to create excellence," the strong atmosphere.

3.3Efforts to promote the backbone of the students to carry out mass self - education.

To carry out mass self education activities, it is an excellent tradition and effective method of military education. In the student team to establish the party members, members of the League branch and district captain, monitor as the main body of the ideological backbone of the team, the backbone of the power is infinite, in the military cadets management, to strengthen the backbone of the training, so that students in the backbone The role of the role of self-discipline to establish self-education. Should be the backbone of the team to shape the structure of the cadres and the party, the organization to contact the trainees of the bridge and link, as the team cadres of the right-hand man. Take the focus on training, self-learning, discussion of the form of communication, the backbone of the church to learn to engage in heart-to-heart activities, the backbone of the ideological thinking of students through extensive contacts, mutual help, organizational learning and learning Lei Feng, learning model and other spiritual civilization to create activities Students play an active role in ideological and political education, the formation of "everyone is a teacher, always educated" self-education a new situation. At the same time, "grant people to fish as a grant to the fishing", to the backbone of the regular replacement team, making the backbone of the team have fresh blood into everyone, everyone can get the organization of exercise, learning to think of management skills, get the organization's approval , More conducive to the first post-graduate team management work.

\section{References}

[1] College students ideological and political education mechanism and method innovation, Zhang Wenbin, national foreign language foreign trade institutions student work association annual meeting, 2007

[2] focus on the quality of research countermeasures - thinking about the 21st century ideological and political education, Liu Dajun, Luo Zhenjiang, "ideological education research", 2000

[3] on the 21st century ideological and political education law exploration, Liu Dajun, Luo Zhenjiang, "Journal of Shanghai Jiaotong University", 2000 